\title{
Boron in Human Nutrition and its Regulations Use
}

\author{
Laura Dinca $^{1}$ and Romulus Scorei ${ }^{2, *}$
}

\author{
${ }^{1}$ University of Craiova, Faculty of Economics and Business Administration, Department of Management \& \\ Marketing, Craiova, Romania \\ ${ }^{2}$ University of Craiova, Faculty of Horticulture, Bioboron Research Institute, Craiova, Romania
}

\begin{abstract}
According to the literature, there are increasingly more scientific data regarding the boron importance in the human nutrition. The request for boron supplements has become more significant due to the following two discoveries: boron transport within the animal cell and the cellular signaling of some bacteria by a sugar borate complex. It is necessary to establish the benefits and the toxicity of boron consumption for humans and animals, although a biological function of boron has not been defined yet. In addition, it is important to know the legal regulations for boron use worldwide, its physiological effects and health uses.
\end{abstract}

Keywords: Nutraceuticals, dietary supplements, boron, nutrition, regulations.

\section{INTRODUCTION}

Boron is a mineral nutrient necessary for the growth and development of vascular plants, marine algae and algal flagellates, diatoms, and cyanobacteria [1], although it is apparently not required by bacteria, fungi, green algae [2]. Boron has not been yet shown to be an essential nutrient in animal cells [3]; more data will probably support this role in the future [4]. Identification of the bacterial quorum sensor autoinducer-2 [5] as a B-containing stable complex, of the transporters responsible for efficient $B$ uptake in animal cells [6] and of the borate ability to inhibit many enzyme systems [7] represents the discoveries of the boron chemistry and constitutes the basis of new drugs and nutraceuticals with boron atom included [7-9]. Thus a nutraceutical is a dietary supplement with the role to enhance health more than the normal foods do it $[10,11]$. Subsequently, a nutraceutical product has health claims and only drug has medicinal claims [12-14]. In this review we intend to present the scientific data about boron compounds and their physiological effects and health uses, as well as the legal regulations for boron use worldwide.

\section{BORON- PHYSIOLOGICAL EFFECTS AND HEALTH USES}

\section{Boron Daily Intake}

People constantly ingest boron from drinking water, mineral water and food. Other sources of boron can be found in various products around people, such as: medicines, cosmetics, toys, detergents, adhesives or

*Address correspondence to this author at the University of Craiova, Faculty of Horticulture, 13, A.I. Cuza, Craiova, Romania; Tel: 0040351407988; Fax:0040251415960; E-mail: romulus_ion@yahoo.com carpets containing boron compounds for their antiseptic, preserving, plasticizing or flame-retardant properties [15]. Borate salts are characterized by an increased solubility, fact that makes them common in animal and plant tissues. They have a higher concentration in plants. On average, the total amount of boron in plants and animals is between $30-50 \mathrm{ppm}$ [15]. The highest boron concentrations are found in many food categories [8]: raw avocado (14.3 ppm), creamy peanut butter (5.87 ppm), salted dry roasted peanuts $(5.83 \mathrm{ppm})$, dry roasted pecans $(2.64 \mathrm{ppm})$, bottled prune juice (5.64 ppm), canned grape juice (3.42 ppm), sweetened chocolate powder (4.29 ppm), table wine $(12.2 \%$ alcohol) (3.64 ppm), prunes with tapioca (3.59ppm), and granola with raisins $(3.55 \mathrm{ppm})$. Low concentrations of boron are found in meat, poultry or fish [8]. In human's tissues and bodily fluids, the most boron is found in the form as boric acid (98.4\%) and as borate anion (1.6\%). Instead of a cellular management, boron has different functions and deposits in distinct tissues and organs. The boron amounts vary among different organs. Thus, in the human body the total boron content is situated between 3 and $20 \mathrm{mg}$, with concentrations of $0.06 \mathrm{ppm}$ in blood, $0.02 \mathrm{ppm}$ in plasma, $0.75 \mathrm{ppm}$ in urine, and between 4.3-17.9 ppm (the highest contents) in bones, nails and hair [3]. The boron content was also found to differ depending on the health of the individual. For example, the concentration of boron was $3 \mathrm{ppm}$ in arthritic bones, relative to $56 \mathrm{ppm}$ in the healthy ones [16]. In human beings, the highest concentrations of boron are found in the heart $(28 \mathrm{ppm})$, followed by the ribs (10 ppm), spleen (2.6 ppm) and liver (2.3 ppm) [17].

Generally, the intake of boron is between 1-3 mg daily, for an unlimited duration. This daily intake of boron varies depending on food selection, the use of 
some specific personal products, and the boron content from water [18]. The daily boron consumption in various areas is different: $0.8-1.9 \mathrm{mg}$ per day in the US, 1.7-7.0 mg per day in the EU, $\sim 0.93 \mathrm{mg}$ per day in Korea, 2.16-2.28 mg per day in Australia, 1.75-2.12 mg per day in Mexico, and 1.80-1.95 mg per day in Kenya [19-22]. These differences are proportional to regional variety in the abundance of food with high energy, and in food products rich in fibers and plant proteins. The World Health Organization (WHO) recommends a Tolerable Intake (TI) (the highest level of daily nutrient intake that is likely to pose no risk of adverse health effects) of $0.4 \mathrm{mg} \mathrm{B} / \mathrm{kg}$ body weight/day for humans [15]. The actual $B$ requirements for the human body remain unclear. In order to clarify that, we will need to have more knowledge about the biological functions of $B$ and the regulation of its exchange [23]. The recommended daily intake of $B$ in humans is between 0.14 and $0.28 \mathrm{mg} /$ day $\mathrm{kg}$ body weight (bw) [24, 25]. However, there are EU recommendations for boron daily intake: $10 \mathrm{mg} \mathrm{B} /$ day for adults and $3 \mathrm{mg} /$ day for 1 $3 \mathrm{yrs} ; 4 \mathrm{mg} /$ day for 4-6 yrs; $5 \mathrm{mg} /$ day for 7-10 yrs; 7 $\mathrm{mg} /$ day for 11-14 yrs; and $9 \mathrm{mg} /$ day for $15-17 \mathrm{yrs}$ [26].

\section{Physiological Effects of Boron Consumption}

The effects of boron consumption may be positive and negative. The lack of boron from the body is harmful for it. This is why boron consumption has positive effects on the body during biological activities. Studies have reported adverse effects like depressed growth, reduced serum steroid hormone concentrations, changes in plasma and organ calcium and magnesium concentrations, plasma alkaline phosphatase and bone calcification on animals' biological functions when their food is deprived in boron [27-31] The improvement of these adverse effects will come by increasing the boron intake [3, 23, 32, 33]. When the level of other nutrients such as cholecalciferol and magnesium is rather low, the negative effects due to low boron intakes are accentuated [34-37]. In fish [38] and frogs [39], there are developmental defects caused by boron deprivation. The same defects have not been found in rodent models [40]. Moreover, it is known that boron interacts with vitamin $\mathrm{D}$, calcium and magnesium in bone formation, influences the estrogen metabolism, and plays a role in the cognitive function [29, 41]. Based on the boron effect on steroid hormones and its interaction with mineral metabolism, it appears to be implicated in clinical diseases [42, 43] (Table 1). According to the present data, a boron supplementation of $200 \mathrm{mg} / \mathrm{L}$ in water represents the optimal dosage for bone development in ostrich chicks, but a high dosage of boron has a negative effect [44]. Also the dietary boron supplements can increase the serum content of boron in osteoporotic rats to stimulate the bone formation and to inhibit the bone resorption, producing an obviously therapeutic effect against osteoporosis [45]. Thus, boron supplements might be useful in the treatment of osteoporosis and in the maintenance of healthy women in the future [31].

Table 1: Boron's Applications in Clinical Nutrition

\begin{tabular}{|c|c|}
\hline Boron's applications & References \\
\hline \hline Arthritis & {$[3,15,17,22,28,30,42]$} \\
\hline Osteoarthritis & {$[30,43,71]$,} \\
\hline Osteoporosis & {$[4,31,35,76]$} \\
\hline Cancer & {$[15,16,17,45,55,56,58,59]$} \\
\hline Cardiovascular diseases & {$[72,74,85]$} \\
\hline
\end{tabular}

The negative effects mainly refer at its toxicity. The $50 \%$ lethal dose of boron as boric acid for one time administration is $2.6 \mathrm{~g}$ per $\mathrm{Kg}$ body weight, relatively close to that of the table salt ( $3 \mathrm{~g}$ per $\mathrm{Kg}$ body weight) [46]. Nevertheless, several case reports deal with boron intoxication in humans. When boric acid is ingested at daily dose levels of $0.14-0.43 \mathrm{~g}$ boric acid $/ \mathrm{Kg}$ body weight (equivalent to about $25-76 \mathrm{mg}$ boron $/ \mathrm{Kg}$ body weight) for days and even weeks, a variety of symptoms appear [24]. The most common are the gastrointestinal ones, such as vomiting, diarrhea and abdominal pain. Besides these, there are others like headache, lightheadedness, and rash [4749]. An ingestion of the equivalent of $0.2 \mathrm{~g} / \mathrm{Kg}$ boron [50] or an exposure to boron oxide and boric acid dust at $4.1 \mathrm{mg} / \mathrm{m}^{3}$ [51] will lead to poisoning. When boron has been used in patients with renal function impairment or in infants and young adults in excessive amounts for more than 3-4 days, safety precautions have been raised $[52,53]$. It was observed that within the first 24 to 48 hours after boric acid ingestion, it increases the urinary riboflavin excretion in approximately two thirds of the patients. These data provide evidence of a previously unrecognized hazard of boric acid ingestion in patients. Boric acid complexes with polyhydroxyl ribitol side chain of riboflavin will increase the water solubility of boric acid [54]. The free boric acid that diffuses freely through the cellular membrane gives the toxicity of boric acid/borate salts. Being in excess, it could also block the cellular metabolic activity, eventually giving apoptosis $[15,55$, 56]. The physiological activity of boron is based on the 
borate anion transporter, called sodium-coupled borate co-transporter 1 ( $\mathrm{NaBC} 1)$, which gives the borate anion to the cell [6]. At a physiological pH (around 7.4), boric acid, in the form of acid, enters the cell through free diffusion and through $\mathrm{NaBC} 1$, and then dissociates into borate [57]. When the extracellular boric acid concentration is high (over $1 \mathrm{mM}$ ), the most boron enters the cell through free diffusion, hydrolyzes as borate anion, and the intracellular $\mathrm{pH}$ decreases [58]. Thus, the cell is subjected to inhibition and then to cellular apoptosis. This happens in the case of cancer cells, too. Boric acid is more toxic for cancer cell than normal cell, due to the fact that former uses less boron for metabolism [57, 58]. For this reason, boron-based compounds are useful in the fight against different types of cancer, especially breast and prostate $[15,16$, $56,59]$. The borate anion and not boric acid seems to be the physiological molecule, but this statement has to be demonstrated. In the case of boron physiological activity, boron has been shown to possess the following features [4]: i) a cell signaling molecule, ii) a co-factor of the enzymes it regulates, iii) a nonenzymatic co-factor, iv) both structural and functional roles, including electron transfer, redox sensing and structural modules, and $v$ ) a role in the cytoskeleton structure. Although boron has not yet been shown to be an essential nutrient in animal cells, more data will probably support such a role in the future. The complexation of borate with organic cisdiols remains the most probable chemical mechanism for the involvement of this element in the evolution of the living world [4].

\section{Boron and its Nutraceutical Use}

The maximum amount of boron the European Food Safety Authority (EFSA) says is safe to consume is 10 $\mathrm{mg}$ boron for an adult per day [25, 26, 60]. This value does not lead to any health risks in conjunction with ongoing ingestion. Boric acid and borax, two very common forms of boron, are used in tablets, capsules, chewable tablets, effervescent powders and liquid formulations as food supplements. The amount of boron, as boric acid or borax, contained in these food supplements was determined by the individual manufacturers. Moreover, in foods, boric acid (E 284) and borax (E 285) may only be used for the preservation of sturgeon roe (caviar), whereby the maximum level of $4 \mathrm{~g} / \mathrm{Kg}$ (calculated as boric acid) should not be exceeded [61].

EFSA's Scientific Panels [62] report that boric $\mathrm{acid} /$ borates cause and effect relationship has not been established between: a) the consumption of boron and the maintenance of normal bone and joints; b) the consumption of boron and maintenance of normal thyroid function; c) the consumption of boron and contribution to normal cognitive function.

The Panel notes the consumption of boron in relation to prostate cancer prevention and treatment means a medical claim and does not comply with the criteria laid down in Regulation (EC) No 1924/2006 as health claim [63]. This reinforces the general idea that the difference between therapy and physiology for boron is correlated with the concentration of ingested boric acid/borates. There is an increasing scientific evidence showing that high intake of boron (20-60 mg B / day) may be considered as a therapy to arthritis, some cancers and general swelling, while the diet supplemented with amounts below $20 \mathrm{mg} \mathrm{B}$ /day has a physiological role, meaning a health claim of boron [59].

Consequently, out of all boron based dietary supplements, only natural plants based-boron compounds must be taken into consideration. Thus, the following natural plants boron compounds have been discovered:

a) Pectic polysaccharide borate complex (rhamnogalacturonan II - RG-II) [1, 7]

b) Sugar alcohol borate complex (fructose borates complexes, glucose borate complexes, fructosesorbitol borate complexes, sorbitol borate complexes, mannitol borate complex, bissucrose borate complexes) $[64,65]$

c) Poyhydroxi organic acid-borate esters (malic acid neutral borate complex, mono-malic acid borate complex, bis (malic acid) borate complex [1]

d) Amino acid-borate esters (Bis- $\mathrm{N}$-acetyl-serine borate complex) [65].

For all these above, the natural counters ions of borate esters complexes with physiological benefic are: calcium, strontium, lithium, magnesium, iron, zinc. It has been reported that boron-RG-II isolated from the walls of sycamore cells and pea stems contains divalent metal cations, such as $\mathrm{Mg}^{2+}, \mathrm{Ca}^{2+}, \mathrm{Sr}^{2+}$ [66-68]. These cations and also $\mathrm{Zn}^{2+}$ are present in boron-RG-II isolated from beet and bamboo [69]. Subsequently new natural boron compounds are expected to be discovered. 
At present, in the nutraceuticals industry, the available nutritional products are: calcium fructoborate, boron citrate, boron aspartate, boron glycinate chelates, and boron ascorbate or boric and sodium borate [8]. Out of the boron based nutraceuticals, the most studied from the scientific point of view is calcium fructoborate, a natural sugar-borate-ester (SBE) [29, 70]. Sugar-borate esters (SBEs) are the esters produced by boric acid and its ionic borate form with different sugars [7, 29]. SBEs are found in fruits and vegetables, and they are naturally absorbed by animal cells [31]. Regarding their toxicity, SBEs are less toxic to normal, healthy cells than other boron-based compounds such as inorganic borates, boric acid, boronates and boranes. In 1998, a study was undertaken to determine the disposition of boron in plasma and urine of rats after single-dose administration of calcium fructoborate (CF), a natural $\mathrm{SBE}$, and boron citrate, via oral gavage. The highest dose of CF administered was $37.5 \mathrm{mg} / \mathrm{Kg}$. No toxicity was noted at this dosage, which is equivalent to 2250 $\mathrm{mg}$ CF (60 mg elemental boron) for a $60 \mathrm{Kg}$ human. Thus, CF, being natural in the food chain, is part of the normal human diet in the world and it is then safe at a level providing a boron intake of several milligrams per day. According to a study from 2001, the median lethal dose for $\mathrm{CF}$ is $18.75 \mathrm{~g} / \mathrm{Kg}$ ( $0.525 \mathrm{~g}$ elemental boron) versus $2.6 \mathrm{~g} / \mathrm{Kg}$ for boric acid (0.462 $\mathrm{g}$ elemental boron) [29]. Regarding the nutritional activity of SBEs, it is mainly given by the mechanism of speciation of these compounds that dissociate into sugar-anion borate esters and borate anion (Figure 1). Due to the high association constants of some sugars like sorbitol, mannitol, fructose and ribose, the free boric acid concentration in solution is practically zero. It appears that many fruit plants that contain high concentrations of sorbitol or fructose have fructoborate complexes, a dietary supplement which is marketed today [28, 70]. CF is commercially marketed and used as a boron food supplement in the prevention and as an adjuvant nutritional in the treatment of osteoporosis and osteoarthritis associated with dyslipidemia [29, 43, 71]. Recently, CF was used as nutritional adjuvant for patients with stable angina pectoris due to their demonstrated anti-inflammatory characteristics [29, 72]. Consequently, dietary supplementation of resveratrol- CF combination improves the life-quality for individuals [72].

\section{Boron and its Pharmaceutical Use}

During the history, boron has been viewed as a poison [73]. More recently, it has been therapeutically used in humans [7, 74]. Oral boron supplements have been used as nutritional adjuvant in the treatment of osteoarthritis [43, 75] and stable angina pectoris [72], or to prevent bone loss $[31,76]$.

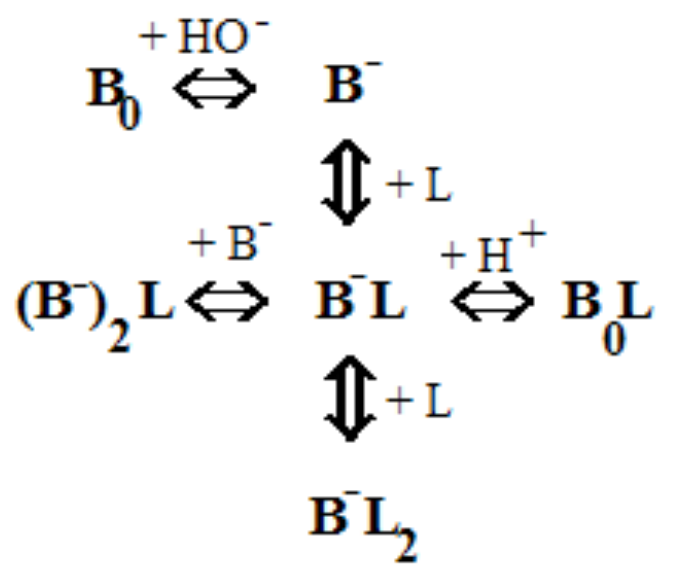

Figure 1: Sugar borate esters' speciation in solution.

$\mathbf{B}_{\mathbf{0}}=$ boric acid; $\mathbf{B}^{-}=$borate anion; $\mathbf{L}=$ sugar ligand (fructose, manitol, sorbitol, glucose); $\mathbf{B}^{-\mathbf{L}}=\mathbf{~ s u g a r}$ borate monoester; $\mathbf{B}^{-}$ $\mathbf{L}_{2}=$ sugar borate diester; $\left(B^{-}\right)_{2} \mathbf{L}=$ sugar diborate monoester; $B_{0} \mathbf{L}=$ sugar boric acid monoester.

In the past, in pharmaceutical preparations, the boric acid was used as a skin and mucosa antiseptic. Nowadays, this application is not valid anymore due to its low efficacy and high toxicity, particularly being linked with the risk of resorptive intoxications in children [77]. On 25 July 1983, the Institute for Medicinal Products of the Federal Health Office from the USA withdrew the marketing authorization for boric acid and its esters and salts in human medicinal products, and the only exceptions were: i) the healing waters and salts produced by them, ii) the ophthalmological preparations containing boric acid or its salts as a buffer and/or isotonisation, iii) the homeopathic dilutions with boric acid or its esters or salts, and iv) the medicinal products with phenyl mercury borate or phenyl mercuric (II) dihydrogen borate [77].

According to literature, the boric acid is also used in vaginal products and contraceptives, in concentrations lower than $1 \%$ [78]. Moreover, tetraborates may be used in concentrations of up to $18 \%$ in bath products and of up to $8 \%$ in wave setting products. Furthermore, boric acid, borates and tetraborates are restricted to be used in powders, oral hygiene products and other products to concentrations of maximum $5 \%, 0.1 \%$ and $3 \%$, respectively (calculated as boric acid). At levels above $1.5 \%$ (calculated as boric acid), they are not permitted to be applied on children under the age of three because they cause irritations and damages of 
the skin. There are no concentration limits for use in denture cleaning products [77]. At present, except for the drug Bortezomib, the most used B-compounds are in cancer treatment by 10-boron neutron capture therapy (BNCT) [16, 59].

\section{BORON USES REGULATIONS}

In accordance with the Dietary Reference Intakes, in the USA boron-based compounds regulated as dietary supplements may provide up to $20 \mathrm{mg}$ of elemental boron equivalents per day [79]. Under the Dietary Supplements Health and Education Act (DSHEA) from 1994, these products have no mandatory pre-market review, but they are not permitted to be labeled or advertised with claims to treat any disease [80].

In Australia, 14 oral boron-containing supplements have been licensed by the Therapeutic Goods Administration (TGA). Their doses were less than or equal to $3 \mathrm{mg}$ boron/day, primarily in combination with calcium, magnesium and vitamin D. The aim of these products is to help in the treatment for symptoms of osteoporosis, in bone remineralization, and in the repairing of connective tissue. For authorized products, there are some specific structure-function claims, such as: i) "boron is important for the bones' metabolism and calcification. It affects calcium, magnesium and phosphorus levels", ii) "boron and vitamin D facilitate the utilization of calcium", iii) "boron is a trace mineral involved in the efficient absorption of calcium in the body", iv) "calcium plus minerals such as boron and magnesium are used for the optimum bone mineralization". In addition, TGA has authorized some boron-containing products with specific health claims related to bone mineralization. There was no cautionary labeling specific to boron, other than the products are for adults only [81].

In 2004, the Scientific Panel on Dietetic Products, Nutrition and Allergies from EFSA established the tolerable upper level (UL) values for boron intake ranging from 3-10 $\mathrm{mg} /$ person/day, depending on the age category [26], with the boron UL of 10 $\mathrm{mg} /$ person/day for adults. Moreover, it was stated that boric acid and sodium borate are suitable for use in foods for particular nutritional purposes, in food supplements and in foods for the general use of population, as long as the above-mentioned UL is not exceeded.
In the United Kingdom, the level of boron present in a number of multi-vitamin and mineral food supplements, but not in licensed medicines, is up to 10 $\mathrm{mg}$ [26]. The safe UL for daily consumption was established at $9.6 \mathrm{mg}$ boron for a $60 \mathrm{Kg}$ adult, based on the no observed adverse effect level (NOAEL) [82]. The maximum estimated boron intake was $14 \mathrm{mg} / \mathrm{day}$, including dietary 97.5 percentile $2.6 \mathrm{mg} /$ day, water 0.6 $\mathrm{mg} /$ day [83], supplements $10 \mathrm{mg} /$ day, cosmetic and consumer products $0.47 \mathrm{mg} / \mathrm{day}$. Although in the EU the boron intakes from food and water are below the UL, the consumption of some supplements containing boron (up to $10 \mathrm{mg} / \mathrm{day}$ ) may lead to intakes exceeding the UL.

In 1994, the Swiss Authority addresses the issue of the risk/benefit ratio of boron and its salts. In Switzerland, there are no approved over-the-counter (OTC) products, including registered vitamin and mineral supplements containing boron [84].

In its International Program on Chemical Safety [83], the World Health Organization (WHO) recommended a tolerable intake ( $\mathrm{TI})$ for boron of 0.4 $\mathrm{mg} / \mathrm{Kg}$ body weight/day for humans, which is equal to $28 \mathrm{mg}$ boron/day for a $70 \mathrm{Kg}$ human adult. This TI was based on the NOAEL of $9.6 \mathrm{mg} / \mathrm{Kg}$ body weight/day from the rat developmental study [82]. This TI was applied because data on boron intake in the EU countries are limited. Boron has the authorization for addition to foods [25]. This applies to boron naturally present in and added to foods. The main dietary sources of boron are plant foods [85]. Supplements may contain $1.5-10 \mathrm{mg}$ boron/dose. Daily intakes of boron from food and water vary from 1 to $7 \mathrm{mg} /$ day, depending on the geographical region and the dietary patterns [20]. Drinking water typically contains less than $1 \mathrm{mg}$ boron/L, albeit the range is large. The mean boron intake from water ranges from 0.2 to $0.6 \mathrm{mg} /$ day [26].

\section{CONCLUSIONS}

Boron is an extremely important element for plants, but is not yet considered essential in animals/humans $[3,73]$. Due to the hypothesis regarding its implications in the extra and intra-cellular cytoskeleton stabilization, boron is probably an essential element in the organism [86]. Moreover, it seems to be an inorganic factor in enzymes and an inter and intra-cellular signaling molecule $[4,31,87]$. All these assumptions are more or less demonstrated and future researches are mandatory for proving them. Thus, we can conclude 
that there is a doubtless future for boron nutraceutical market. However, further researches will prove its property as an essential nutrient for humans.

\section{DECLARATION OF INTEREST}

The authors declare that they have no competing interests. The authors alone are responsible for the content and writing of this paper.

\section{REFERENCES}

[1] Dembitsky VM, Smoum R, Al-Quntar AAA, Ali HA, Pergament I, Srebnik M. Natural occurrence of boroncontaining compounds in plants, algae and microorganisms. Plant Sci 2002; 163: 931-42. http://dx.doi.org/10.1016/S0168-9452(02)00174-7

[2] Loomis WD, Durst RW. Chemistry and Biology of Boron. BioFactors 1992; 3: 229-39.

[3] Hunt CD. Dietary boron: Progress in establishing essential roles in human physiology. J Trace Elem Exp Med 2012; 26: 157-60.

http://dx.doi.org/10.1016/j.jtemb.2012.03.014

[4] Scorei R. Is boron a prebiotic element? A mini-review of the essentiality of boron for the appearance of life on Earth. Orig Life Evol Biosph 2012; 42(1): 3-17. http://dx.doi.org/10.1007/s11084-012-9269-2

[5] Chen X, Schauder S, Potier N, Van Dorsselaer A, Pelezer I, Bassler BL, Hughson FM. Structural identification of a bacterial quorum-sensing signal containing boron. Nature 2002; 415: 545-49.

http://dx.doi.org/10.1038/415545a

[6] Park M, Li Q, Shcheynikov N, Muallen S, Zeng W. NaBC1 is a ubiquitous electrogenic $\mathrm{Na}$-coupled borate transporter essential for cellular boron homeostasis and cell growth and proliferation. Mol Cell 2004; 16 (3): 331-41. http://dx.doi.org/10.1016/j.molcel.2004.09.030

[7] Dembitsky VM, Al-Quntar AAA, Srebnik M. Natural and Synthetic Small Boron-Containing Molecules as Potential Inhibitors of Bacterial and Fungal Quorum Sensing. Chem Rev 2011; 111: 209-37. http://dx.doi.org/10.1021/cr100093b

[8] Hunt CD. Boron. In: Encyclopedia of dietary supplements. 2nd Ed. New York, London: Informa Healthcare 2010; pp. 82-90.

[9] Nieves JW. Skeletal effects of nutrients and nutraceuticals, beyond calcium and vitamin D. Osteoporos Int 2012; Nov 14. http://dx.doi.org/10.1007/s00198-012-2214-4

[10] Biesalski HK. Nutraceuticals: the link between nutrition and medicine. In: Nutraceuticals in health and disease prevention. Kramer K, Hoppe PP, Packer L, Eds. New York: Marcel Dekker Inc. 2001; pp. 1-26. http://dx.doi.org/10.1201/9780203908174.ch1

[11] Zeisel SH. Regulation of "Nutraceuticals". Science 1999; 285: 185-186. http://dx.doi.org/10.1126/science.285.5435.1853

[12] Gulati OP, Ottaway PB. Legislation relating to nutraceuticals in the European Union with a particular focus on botanicalsourced products. Toxicol 2006; 221: 75-87. http://dx.doi.org/10.1016/j.tox.2006.01.014

[13] EU Commission (2003) Proposal for a Regulation of the European Parliament and of the Council on Nutrition and Health Claims Made on Foods. COM 0165 dated 16.07.2003; pp. 11-19.
Reuterswärd AL. The new EC Regulation on nutrition and health claims on foods. Scand J Food Nutr 2007; 51(3): 100106.

http://dx.doi.org/10.1080/17482970701685625

[15] Meacham S, Karakas S, Wallace A, Altun F. Boron in Human Health: Evidence for Dietary Recommendations and Public Policies. OMPJ 2010; 3: 36-53.

[16] Scorei R, Popa R. Boron-containing compounds as preventive and chemotherapeutic agents for cancer. AntiCancer Agents Med Chem 2010; 10: 346-51. http://dx.doi.org/10.2174/187152010791162289

[17] Devirian TA, Volpe SL. The physiological effects of dietary boron. Crit Rev Food Sci Nutr 2003; 43(2): 219-31. http://dx.doi.org/10.1080/10408690390826491

[18] Becking GC, Chen B-H (International programme on chemical safety (IPCS) environmental health criteria on boron human health risk assessment. Biol Trace Elem Res 1998; 66(1-3): 439-50. http://dx.doi.org/10.1007/BF02783154

[19] Rainey CJ, Nyquist LA. Multicountry estimation of dietary boron intake. Biol Trace Elem Res 1998; 66: 79-86. http://dx.doi.org/10.1007/BF02783128

[20] Richold M. Boron Exposure from consumer products. Biol Trace Elem Res 1998; 66: 121-29. http://dx.doi.org/10.1007/BF02783132

[21] Rainey CJ, Nyquist LA, Christensen RE, Strong PL, Culver $\mathrm{BD}$, Coughlin JR. Daily boron intake from the American diet. J Am Diet Assoc 1999; 99: 335-40. http://dx.doi.org/10.1016/S0002-8223(99)00085-1

[22] Bakirdere S, Örenay S, Korkmaz M. Effect of Boron on Human Health. OMPJ 2010; 3: 54-59.

[23] Nielsen FH. Is boron nutritionally relevant? Nutr Rev 2008; 66(4): 183-91.

http://dx.doi.org/10.1111/j.1753-4887.2008.00023.x

[24] EPA (United State Environmental Protection Agency). Health Effects Support Document for Boron. 2008; Available from: http://www.epa.gov/ogwdw/ccl/pdfs/reg_determine2/healtheff ects_ccl2-reg2_boron.pdf

[25] SCCS (Scientific Committee on Consumer Safety). Opinion on boron compounds. 22 June 2010; Avalaible from: $\mathrm{http}: / /$ ec.europa.eu/health/scientific_committees/consumer_s afety/docs/sccs_o_027.pdf

[26] EFSA (European Food Safety Authority). Opinion of the Scientific Panel on Dietetic Products, Nutrition and Allergies on a request from the Commission related to the Tolerable Upper Intake Level of Boron (Sodium Borate and Boric Acid). EFSA Journal 2004; 80: 1-22.

[27] Woods WG. Review of possible boron speciation relating to its essentiality. J Trace Elem Exp Med 1996; 9(4): 153-63. http://dx.doi.org/10.1002/(SICI)1520670X(1996)9:4<153::AID-JTRA3>3.0.CO;2-S

[28] Miljkovic D, Scorei IR, Cimpoiasu VM, Scorei ID. Calcium fructoborate: plant based dietary boron for human nutrition. $J$ Diet Suppl 2009; 6: 211-26. http://dx.doi.org/10.1080/19390210903070772

[29] Scorei RI, Rotaru P. Calcium Fructoborate - Potential antiinflammatory agent. Biol Trace Elem Res 2011; 143 (3): 1223-38. http://dx.doi.org/10.1007/s12011-011-8972-6

[30] Nielsen FH, Meacham S. Growing evidence for human health benefits of boron. JEBCAM 2011; 16: 169-80. http://dx.doi.org/10.1097/00017285-199205000-00003

[31] Scorei R. Regulation of therapeutic potential of boroncontaining compounds. In: Kretsinger $\mathrm{H}$, Uversky VN, Permyakov EA, Eds. Encyclopedia of Metalloproteins. Springer 2013; 1400: p. 100 illus. 
[32] Nielsen FH. Facts and fallacies about boron. Nutr Today 1992; 27: 6-12.

[33] Nielsen FH. Biochemical and physiologic consequences of boron deprivation in humans. Environ Health Perspect 1994; 102(7): 59-63.

http://dx.doi.org/10.1289/ehp.94102s759

[34] Benderdour M, Hess K, Dzondo-Gadet M, Nabet P, Belleville $F$, Dousset B. Boron modulates extracellular matrix and TNF alpha synthesis in human fibroblasts. Biochem Biophys Res Commun 1998; 246(3): 746-51.

http://dx.doi.org/10.1006/bbrc.1998.8688

[35] McCoy H, Kenney MA, Montgomery C, Irwin A, Williams L, Orrell R. Relation of boron to the composition and mechanical properties of bone. Environ Health Perspect 1994; 102(7): 49-53 http://dx.doi.org/10.1289/ehp.94102s749

[36] Hunt CD. The biochemical effects of physiologic amounts of dietary boron in animal nutrition models. Environ Health Perspect 1994; 102(7): 35-43. http://dx.doi.org/10.1289/ehp.94102s735

[37] Hunt CD. Biochemical effects of physiological amounts of dietary boron. J Trace Elem Exp Med 1996; 9: 185-13. http://dx.doi.org/10.1002/(SICI)1520670X(1996)9:4<185::AID-JTRA6>3.0.CO;2-Q

[38] Rowe RI, Eckhert CD. Boron is required for zebrafish embryogenesis. J Exp Biol 1999; 202(12): 1649-54.

[39] Fort DJ. Boron deficiency disables Xenopus laevis oocyte maturation events. Biol Trace Elem Res 2002; 85(2): 157-69. http://dx.doi.org/10.1385/BTER:85:2:157

[40] Lanoue L, Taubeneck MW, Muniz J, Hanna LA, Strong PL, Murray FJ, Nielsen FH, Hunt CD, Keen CL. Assessing the effects of low boron diets on embryonic and fetal development in rodents using in vitro and in vivo model systems. Biol Trace Elem Res 1998; 66(1-3): 271-98. http://dx.doi.org/10.1007/BF02783143

[41] Meacham SL, Taper LJ, Volpe SL. Effects of boron supplementation on bone mineral density and dietary, blood, and urinary calcium, phosphorus, magnesium, and boron in female athletes. Environ Health Perspect 1994; 102: 79-82.

[42] Newnham RE. Essentiality of boron for healthy bones and joints. Environ Health Prospect 1994; 102(7): 83-85. http://dx.doi.org/10.1289/ehp.94102s783

[43] Scorei R, Mitrut P, Petrisor I, Scorei ID. A double-blind, placebo-controlled pilot study to evaluate the effect of calcium fructoborate on systemic inflammation and dyslipidemia markers for middle-aged people with primary osteoarthritis. Biol Trace Elem Res 2011; 144(1-3): 253-63. http://dx.doi.org/10.1007/s12011-011-9083-0

[44] Cheng J, Peng $\mathrm{K}$, Jin $\mathrm{E}$, Zhang $\mathrm{Y}$, Liu $\mathrm{Y}$, Zhang $\mathrm{N}$, et al. Effect of additional boron on tibias of African ostrich chicks. Biol Trace Elem Res 2011; 144(1-3): 538-49. http://dx.doi.org/10.1007/s12011-011-9024-y

[45] Hosmane NS, Ed. Boron Science: New Technologies and Applications. CRC Press, Northern Illinois University, Dekalb, USA 2011

http://dx.doi.org/10.1201/b11199

[46] Baker SJ, Tomshob JW, Benkovicc SJ. Boron-containing inhibitors of synthetases. Chem Soc Rev 2011; 40: 4279-85. http://dx.doi.org/10.1039/c0cs00131g

[47] Ishii Y, Fujizuka N, Takahashi T, Shimizu K, Tuchida A, Yano $\mathrm{S}$, et al. A fatal case of acute boric acid poisoning. Clin Toxicol 1993; 31(2): 345-52. http://dx.doi.org/10.3109/15563659309000402

[48] Culver BD, Hubbard SA. Inorganic boron health effects in humans: an aid to risk assessment and clinical judgment. J Trace Elem Exp Med 1996; 9: 175-84.

http://dx.doi.org/10.1002/(SICI)1520-

670X(1996)9:4<175::AID-JTRA5>3.0.CO;2-Q
[49] Craan AG, Myres AW, Green DW. Hazard assessment of boric acid in toys. Reg Tox Pharm 1997; 26: 271-80.

http://dx.doi.org/10.1006/rtph.1997.1155

[50] Linden $\mathrm{CA}$, Alan $\mathrm{AH}$, Kulig KW, Rumack $\mathrm{BH}$. Acute ingestion of boric acid. Clin Toxicol 1986; 24: 260-79.

http://dx.doi.org/10.3109/15563658608992592

[51] Garabrant DH, Bernstein L, Peters JM, Smith TJ. Respiratory and eye irritation from boron oxide and boric acid dusts. J Occup Med 1984; $26: 584-86$. http://dx.doi.org/10.1097/00043764-198408000-00013

[52] Teshima D, Morishita K, Ueda Y, Futagami K, Higuchi S, Komoda $\mathrm{T}$, et al. Clinical management of boric acid ingestion: pharmacokinetic assessment of efficacy of hemodialysis for treatment of acute boric acid poisoning. $\mathrm{J}$ Pharmacobiodyn 1992; 15(6): 287-94. http://dx.doi.org/10.1248/bpb1978.15.287

[53] Pahl MV, Culver BD, Vaziri ND. Boron and the kidney. J Ren Nutr 2005; 15(4): 362-70. http://dx.doi.org/10.1053/j.jrn.2005.05.001

[54] Pinto J, Huang YP, McConnell RJ, Rivlin RS. Increased urinary riboflavin excretion resulting from boric acid ingestion. J Lab Clin Med 1978; 92(1): 126-34.

[55] Scorei R, Ciubar R, Ciofrangeanu CM, Mitran V, Cimpean A lordachescu D. Comparative effects of boric acid and calcium fructoborate on breast cancer cells. Biol Trace Elem Res 2008; 122: 197-205. http://dx.doi.org/10.1007/s12011-007-8081-8

[56] Scorei R. Boron Compounds in the Breast Cancer Cells. Chemoprevention and Chemotherapy. In: Breast Cancer Current and Alternative Therapeutic Modalities ISBN 978 953-307-776-5 Edited by: Esra Gunduz and Mehmet Gunduz InTech 2011; pp. 92-114.

[57] Park M, Li Q, Shcheynikov N, Muallen S, Zeng W. Borate transport and cell growth and proliferation: not only in plants. Cell Cycle 2005; 4(1): 24-26. http://dx.doi.org/10.4161/cc.4.1.1394

[58] Barranco WT, Eckhert CD. Boric acid inhibits human prostate cancer cell proliferation. Cancer Lett 2004; 216(1): 21-29. http://dx.doi.org/10.1016/j.canlet.2004.06.001

[59] Scorei RI, Popa R. Sugar-Borate Esters-Potential Chemical Agents in Prostate Cancer Chemoprevention. AntiCancer Agents Med Chem 2013; (in press).

[60] EC (European Commission. Scientific Committee on Food). Tolerable Upper Intake Levels for Vitamins and Minerals.2006. Avalilable from:http://ec.europa. $\mathrm{eu} / \mathrm{comm} . / \mathrm{food} / \mathrm{fs} / \mathrm{sc} / \mathrm{scf} /$ out80 en.htm.

[61] Commission Regulation (EU) No. 1129/2011 amending Annex II to Regulation (EC) No. 1333/2008 of the European Parliament and of the Council by establishing a Union list of food additives (OJ No. L 295, 12.11.2011, p. 1) ("Regulation 1129/2011")

[62] EFSA (European Food Safe Authorithy). Scientific Opinion on the substantiation of health claims related to boron and prevention and treatment of prostate cancer (ID 221), maintenance of normal thyroid function (ID 222) and contribution to normal cognitive function (ID 223) pursuant to Article 13(1) of Regulation (EC) No 1924/20061. EFSA Journal 2011; 9(6): 2209, 1-14

[63] Commission Regulation (EU) No 1924/2006 of the European Parliament and of the Council of 20 December 2006 on nutrition and health claims made on foods (OJ No. L 404, 30.12.2006, p. 10)

[64] $\mathrm{Hu} \mathrm{H}$, Penn S, Lebrillo C, Brown PH. Isolation and characterization of soluble boron complexes in higher plants. Plant Physiol 1997; 113: 649-55.

http://dx.doi.org/10.1104/pp.113.2.649

[65] Stangoulis J, Tate M, Graham R, Bucknall M, Palmer L, Boughton $\mathrm{B}$, Reid $\mathrm{R}$. The mechanism of boron mobility in 
wheat and canola phloem. Plant Physiol 2010; 153(2): 87681.

\section{http://dx.doi.org/10.1104/pp.110.155655}

[66] Lutz O, Humpfer E, Spraul M. Ascertainment of boric-acid esters in wine by 11B-NMR. Naturwissen 1991; 78: 67-69. http://dx.doi.org/10.1007/BF01206257

[67] Pellerin P, Doco T, Vidal S, Williams P, Brillouet JM, O'Neill MA. Structural characterization of red wine rhamnogalacturonan II. Carbohydr Res 1996; 290(2): 18397.

\section{http://dx.doi.org/10.1016/0008-6215(96)00139-5}

[68] O'Neill MA, Warrenfeltz D, Kates K, Pellerin P, Doco T, Darvill AG, Albersheim P. Rhamnogalacturonan-II, a pectic polysaccharide in the walls of growing plant cell, forms a dimer that is covalently cross-linked by a borate-ester. J Biol Chem 1996; 271: 22923-30.

http://dx.doi.org/10.1074/jbc.271.37.22923

[69] Matsunaga T, Nagata T. In vivo 11B-NMR observation of plant tissue. Anal Sci 1995; 11: 889-92. http://dx.doi.org/10.2116/analsci.11.889

[70] Rotaru P, Scorei R, Harabor A, Dumitru MD. Thermal analysis of a calcium fructoborate sample. Thermochim Acta 2010; 506: 8-13.

http://dx.doi.org/10.1016/j.tca.2010.04.006

[71] Reyes-Izquierdo T, Nemzer B, Gonzalez AE, Zhou Q, Argumedo R, Shu C, Pietrzkowski ZB. Short-term intake of calcium fructoborate improves WOMAC and McGill scores and beneficially modulates biomarkers associated with knee osteoarthritis: a pilot clinical double-blinded placebocontrolled study. J Biomed Sci 2012; 4(2): 111-22.

[72] Militaru C, Donoiu I, Craciun A, Scorei ID, Bulearca AM, Scorei RI. Oral resveratrol and calcium fructoborate supplementation in subjects with stable angina pectoris: Effects on lipid profiles, inflammation markers, and quality of life. Nutrition 2013; 29(1): 178-83.

http://dx.doi.org/10.1016/j.nut.2012.07.006

[73] Nielsen FH. The saga of boron in food: from a banished food preservative to a beneficial nutrient for humans. Curr Topics Plant Biochem Physiol 1991; 10: 274-86.

[74] Groziak MP. Boron therapeutics on the horizon. Am J Ther 2001; 8(5): 321-328. http://dx.doi.org/10.1097/00045391-200109000-00005

[75] Travers RL, Rennie GC, Newnham RE. Boron and arthritis: The tesults of a double-blind pilot study. J Nutr Environ Med 1990; 1(2): 127-32. http://dx.doi.org/10.3109/13590849009003147

[76] Hakki SS, Bozkurt BS, Hakki EE. Boron regulates mineralized tissue-associated proteins in osteoblasts (MC3T3-E1). J Trace Elem Exp Med 2010; 24(4): 243-50. http://dx.doi.org/10.1016/i.jtemb.2010.03.003
Federal Institute for Risk Assessment (BfR) (Bundesinstitut für Risikobewertung) () Addition of boric acid or borax to food supplements. BfR Health Assessment 2006; 006. Available from: http://www.bfr.bund.de/cm/245/addition_of_boric_acid_ or_borax_to_food_supplements.pdf (9 November 2009)

[78] Moore JA. An assessment of boric acid and borax using the IEHR Evaluative process for assessing human developmental and reproductive toxicity of agents. Reprod Toxicol 1997; 11(1): 123-60. http://dx.doi.org/10.1016/S0890-6238(96)00204-3

[79] IoM (Institute of Medicine). Dietary Reference Intakes for Vitamin A, Vitamin K, Arsenic, Boron, Chromium, Copper, lodine, Iron, Manganese, Molybdenum, Nickel, Silicon, Vanadium, and Zinc. National Academies Press, Washington DC. 2000.

[80] Dietary Supplement Health Education Act (DSHEA) of 1994. Public Law 103-417, available from FDA website: http://www.fda.gov.

[81] Australian Register of Therapeutic Goods [homepage on the Internet]. Available from: http://www.tga.gov.au/index.htm; (Australian web site advertisements for authorized products cited in the Registry; personal communication from TGA to the NHPD, February 2007)

[82] Price CJ, Strong PL, Marr MC, Myers CB, Murray FJ. Developmental toxicity NOAEL and postnatal recovery in rats fed boric acid during gestation. Fund Appl Toxicol 1996; 32: 179-93.

http://dx.doi.org/10.1006/faat.1996.0121

[83] IPCS (International Programme on Chemical Safety). Environmental Health Criteria 204: Boron. World Health Organization, Geneva, Switzerland 1998. Available from: http://www.inchem.org/documents/ehc/ehc/ehc204.htm

[84] Health Canada. Boron as a Medicinal Ingredient in Oral Natural Health Products. 2007. Available from: http://www.hcsc.gc.ca/dhp-mps/pubs/natur/boron-bore-eng.php

[85] Naghii MR, Samman S. The effect of boron supplementation on its urinary excretion and selected cardiovascular risk factors in healthy male subjects. Biol Trace Elem Res 1997; 56: 273-86. http://dx.doi.org/10.1007/BF02785299

[86] Bassil E, Hu H, Brown PH. Use of Phenylboronic Acids to Investigate Boron Function in Plants. Possible Role of Boron in Transvacuolar Cytoplasmic Strands and Cell-to-Wall Adhesion. Plant Physiol 2004; 136(2): 3383-5. http://dx.doi.org/10.1104/pp.104.040527

[87] Bolaños L, Lukaszewski K, Bonilla I, Blevins D. Why boron? Plant Physiol Biochem 2004; 42: 907-12. http://dx.doi.org/10.1016/j.plaphy.2004.11.002

(c) 2013 Dinca and Scorei; Licensee Lifescience Global.

This is an open access article licensed under the terms of the Creative Commons Attribution Non-Commercial License (http://creativecommons.org/licenses/by-nc/3.0/) which permits unrestricted, non-commercial use, distribution and reproduction in any medium, provided the work is properly cited. 